\title{
The Stumble of a Comedian
}

\author{
Maria Shera Sofhia Lopez Becerra \\ Universidad Pedagógica y Tecnológica de Colombia \\ maria.lopez31@uptc.edu.co
}

The atmosphere was completely tense, very cold and so dark. At that spot, you couldn't hear a single soul pleading. Constantly, mice were crossing, and their petite paws gave the sensation that they were covering your body. Those little ones were trying to avoid their own death.

At that point, the hostile environment broke. A convicted felon got out of state in abduction, thanks to some squeaks. He noticed some of them, even himself, were in a kind of psychological torture. The agony didn't have the intention of being part of so many resignation techniques. It was mostly a community service, a philanthropic action. Being this, one of the most commemorative works never done. It was a comedy show.

At the state jail, they had taken this measure months ago as a way to bribe the convicts. This was because three guards has died previous weeks ago. However, that benefit action was one of the worst.

The guest who was on stage, blinded by the light, was a guy about 32 years old. He clearly had overweight issues, and he wore beautiful thick frame glasses. Actually, nothing particularly handsome identified this man. He was a comedian, with such stunning standards he came. Around there it was said that he was one of the best, even though he was a rookie.

No one had any idea how long he would be on stage. Maybe 10 minutes of a half-hour or more. Indeed, it was an infinite torture.

His jokes killed the mood. He was talking and talking and never shut up. He lacked any kind of humor. Time seeemed vicious and eternal. The security guards didn't escape the trance. Some were nodding trying to hide the state of drowsiness. Looking at each other, as if they were communicating telepathically, they understood the desperation that came from there. 
In a moment, the comedian stopped his own show by himself due to his foggy glasses. The comedian was sweating till the last drop of modesty. It seemed that the heat in the room had been turned up, but it obviously had not.

Meanwhile, he was preparing and taking a deep breath. He tried to find a smile while looking at his audience. Instead, there were several frowning faces. He clearly knew his show was not going well.

He slowly opened his mouth to recite the next lines, however he was in shock. He had forgotten them. His mind went blank. He was trying with all resources available, but none of them worked. He looked frozen. He turned his gaze to the guards, but his emotions remained unabated. He thought about how quickly the guards could draw their weapons and open fire.

He was debating with himself. He wasn't sure whether to continue or not. His nerves didn't allow him to think clearly, but he needed the money more than ever since he had an enormous debt. It seemed like his only option would be to lose a few fingers. As by the work of the Holy Spirit, news had reached him about the request of a comedian for a presentation in the state jail. So, he grabbed material where he best could and reiterated his convictions. However, it would be a show in decline or the beginning of losing each one of his fingers.

With a streak of miracles without stopping, he remembered a funny anecdote that he had heard about an inmate and a guard, who had been caught in a somewhat awkward position. But there was no merit behind the story; it had only remained as a simple rumor.

The way he retold the story seemed calmer, more confident. Perhaps because he would believe that by saying such a thing, everyone would laugh and ease the situation. Maybe it was because of his homophobia, he felt superior telling the story, knowing deep inside of him that he was trying to hide such a part of his life.

When the joke ended, he waited a while to receive their applause or laughter. Nevertheless, an unexpected silence greeted him. He did not understand what was going on. He was looking at everyone, no one seemed happy. Their expressions were of fear and astonishment, as if they didn't believe what was happening. Then, he glanced at the guards, the looks did not differ.

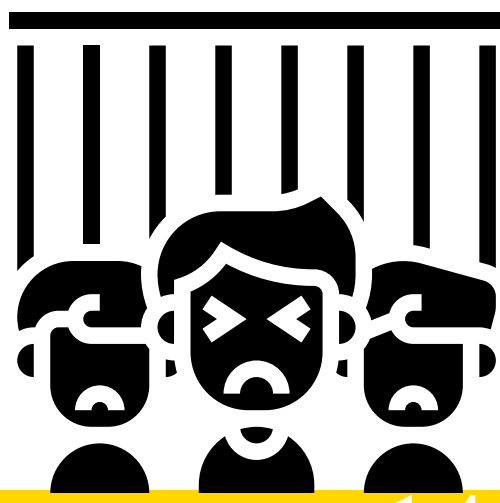


By some magnitude, his perspective was focused on one of the convicts. The only thing he felt were chills that completely invaded him. His heart slowed down and paranoia crept into his bones, as if his worst nightmare was living in his own flesh.

Without thinking so much, he wanted to leave alive from that stage.

He instantly dropped the mic and got off the stage. He was getting to the door when the guards surprised him by blocking the way." But? What are you doing !? Let me out right now!" yelled the commedian.

None of the guards responded. He tried to push them away but was unable to use his great weight to his advantage. He hit the guards again to no avail. Instead, he was humiliated by falling to the ground. He did not realize when he was cornered, even the guards had locked him up.

Among the crowd, a prisoner emerged. About 5ft. 4in. tall, dark, with several scars on his face, and tattoos were not lacking. In a hoarse voice he said, "No one should know that information. I myself made sure of that, apparently I did not do my job well. That fag you were making fun of! he has it in mind ..."

The comedian pleaded, "No! Look, my intentions weren't to make fun of someone ... I ... eh"

"Shut up!" said the convict. Then, the comedian was hit in the face by the gaoler.

Then, the gaoler said "I did not come here for a fat and failed comedian to come and make fun of me. I came here to have fun, more than I have here."

"Look, I ... my apologies..." Puf! He was hit again. He tried to say something, but his whining stopped him.

The prisoner said, "You know what? Let's teach this jerk a lesson!"

This is how this week's scoop ends. The bloody finale starring a failed comedian. He was carried out by convicts and presumably by some guards, who also participated. This situation was worthy of a crime scene.

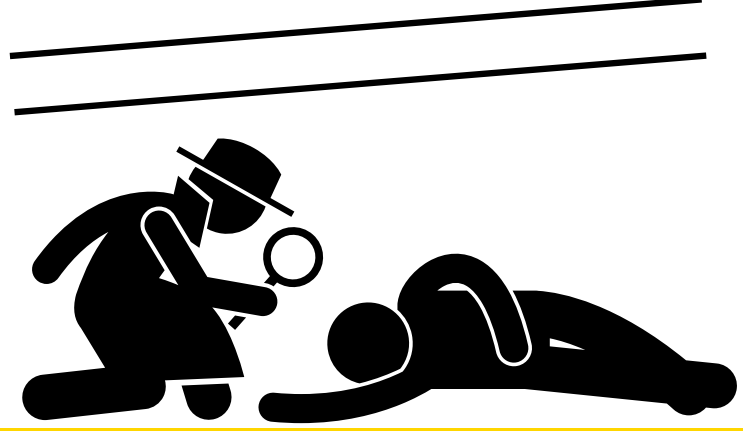

